\title{
RHETORICAL ANALYSIS OF PRESIDENT TRUMP POLITICAL SPEECH IN PALM BEACH, FLORIDA ON JANUARY 3RD, 2020 ON THE KILLING OF QASSEM SOLEIMANI
}

\section{Reski Amaliah Haming,* Jumharia Djamereng, Nuri Emmiyati}

\author{
English and Literature Department, Faculty of Adab and Humanities, \\ UIN Alauddin Makassar, Indonesia \\ e-mail: reskiamaliah676@gmail.com
}

\begin{abstract}
This research analyzes rhetoric which is uttered by President Trump in his political speech in Palm Beach, Florida on January 2020 on the killing of Qassem Soleimani. The analysis involves its context, arguments, and also the effects caused by his speech. The research method used is descriptive qualitative method. The data were taken from the video, the transcript of the speech and the news related to the speech. Martin theory (2014) of rhetorical analysis on political speech and Cicero's theory in Aristotle (2008) of the classical principle of rhetoric are used to analyze the data. The research results are the rhetorical context of President Trump`s speech is to respond and clarify the killing of Qassem Soleimani; and the accusation of started a war, thus the rhetorical argument shows that the speech used all the classical principle of rhetoric and the rhetorical effect of the speech is escalating the tension in the region.
\end{abstract}

Keywords: Political speech, rhetorical analysis, president Trump, Qassem Soleimani

\section{INTRODUCTION}

In the early of 2020, the world was shocked of the news world war III because the death of Iran general Qassem Soleimani by United States military member. The news spreads quickly across the world through online media and social media. It might be seen from the \#WWIII reached one million tweets at the day and led the worldwide trends on twitter. Meanwhile President Trump, the president of United States when the killing of Qassem Soleimani occurred, was raised a speech in Palm Beach, Florida on January 3rd 2020 to respond and clarify the news. The speech appertained as political speech.

Political speech represent a well-planned and arranged sentence that made by a political actor used to persuade the citizen (Sutherland, 2016). The speeches that concerning political terms are usually intended to convey ideas and information, and also to convince audiences that relates to their political claim which are acceptable, logical, and implementable (Syarif, 2015). Conveying a political speech with a good rhetoric will make the audience be dazzled by the beautiful sentence that full of persuasive words without 
realizing the hidden meaning behind it. A political actor that used to deliver a political speech such us a president or a minister will be really a good orator in conveying his ideas without unrealized as planned speech or discourse because of the higher frequency of giving a speech (Sutherland, 2016). To be aware of political speech message, the analysis of rhetoric is the way to analyze it. Based on Martin`s point of view, Political speech structure can be analyzed through rhetorical approaches to know further about its context, argument and effect (Martin, 2015).

Rhetoric has been developed in fifth century under Syracuse and Athens democracies that expected to give an effective speech and to teach everyone how to plan and deliver it because under democracy everyone is hoped conveying his opinion and participating in political communication (G. A. Kennedy, 1994). After more than 2000 years since rhetoric had been discovered, it is still quite difficult to define. Aristotle, one of the greatest orators in classical period stated that "rhetoric is the faculty of discovering in any given case the available means of persuasion"(Aristotle, 2008).

Rhetorical analysis underscores the situated nature of ideas, that is, their presence in speech and argument delivered at, and in response to, specific times and places (Martin, 2015). It really relates to the President Trump political speech on the killing of Qassem Soleimani. The speech was delivered in a specific time, place and so on. It already fulfills the elements of rhetorical analysis specifically on political speech.

Based on the background of the study explained above, the writer is interested to study how is the President Trump political speech`s on the killing of Qassem Soleimani arguments arranged and its context? That known has not political background, but always be a controversial President because of his idea. And for further research, the writer is really interested in knowing how is the rhetorical effect of the President Trump political speech on the killing of Qassem Soleimani?

\section{LITERATURE REVIEW}

Discourse means the text, that is, the language used, plus the context in which it appears (Sutherland, 2016). Every discourse has its own reason to be released in certain context. In the history, written discourse played the most important form of language instead of spoken discourse. But the development of technology that allows words to be recorded has brought bigger effect for spoken discourse. Now it recognized having an important role in social interaction for instance in developing and maintaining the social relation of human being.

Defining rhetoric is not an easy thing. Developed under Greek democracy in the fifth century B.C.E, rhetoric has been used for persuasive communication strategies in crucial areas of social life such us public affairs, law courts, civil disputes and education (Ilie, 2006). It caused the emergent of three distinct approaches in classical period that were the Sophistical, the Aristotelian and the Platonic (Szczesny, 2017). The Sophists were the first teacher of rhetoric that itinerant lectures at the time where rhetoric was known as formal education for young men (G. A. Kennedy, 1994). They considered rhetoric was a tactic to make a week argument be stronger 
through language creativity (Szczesny, 2017). Then the Aristotelian concerned rhetoric was the way of persuading by using the means of persuasion based on his definition in his book that "rhetoric is the faculty of discovering in any given case the available means of persuasion" and also considered persuasion in rhetoric was a crucial aspect of speech (Aristotle, 2008). And Platonic, cited in Illie`s journal article (2016) they considered rhetoric as "the art of winning the soul by discourse". From three distinct approaches arose in classical Greece period it cannot be separated from Roman period that also had already been discovered by one of the greatest Roman orator, Markus Tullius Cicero. And it becomes a thought base of rhetoric until nowadays that we might sometime define rhetoric as the art of using language or the art of persuasion.

\section{Theory of Rhetorical Analysis}

Rhetorical analysis should be concerned with three distinctmoments of a speech intervention, each of which combines structure and agency in a particular way and hence serves as a separate area for interpretation (Martin, 2015):

\section{The rhetorical context}

The rhetorical context emphasizes on immediate conditions giving rise to a speech occasion (Martin, 2015). Endeavors for indentifying and explain how variables such us audience, occasion, exigency, purpose, text and writer in a setting interact with one another to shape if, when, how, and what people (Moxley, 2019). This rhetorical context refers to broader understanding and interpreting that involves identifying the historical time and place of the speech, to which event it responses or conveying. And also to the circumstances the speech delivered at involves the audience of the speech.

\section{The rhetorical argument}

Concerning the rhetorical argument which considers the situation configured in the language of the speech itself or the moment where ideas are shaped into an argument for audiences (Martin, 2015). Rhetorical argument comprises five of the classical principles of rhetoric based on Cicero`s classical principles of rhetoric to know further about how argument planned, structured and delivered. The principles consists invention (inventio), arrangement (dispotio), style (elocutio), memory (memoria) and delivery (pronuntiato/action). (See Cicero`s Ideas of rhetorical principles).

\subsection{Invention/Discovery (inventio)}

Invention or discovery is the first principle of classical rhetoric which refers to the process of thinking out the subject matter by identifying the question at issue (stasis of the speech) or the fact about the issue (did he or she really do it? Did she or he admit his or her action that accused on him or her?) . And the second is identifying the available means of persuading audience to accept the speaker's position (Kennedy, 1994). There are three means of effecting persuasion, reasoning logically (logos), understanding 
human character and goodness in their various forms (ethos), and understanding the emotion (pathos) (Aristotle, 2008).

\subsubsection{Three Means of Persuasion}

The moment of the speaker's reasoning on ideas that he or she stands for by using two reasoning ways or techniques is called logos (Ilie, 2006). Both of them are inductive and deductive techniques. Inductive is a technique of reasoning which based on a particular case. While deductive is a technique of reasoning which based on a general principle (Martin, 2014). Instead of both techniques of reasoning that consist major premise, minor premise and conclusion (syllogism), Aristotle has his own strategy to analyze deeply on the way an orator reasoning logically which is enthymeme and example that he believed that many speakers while delivered a speech do not put all the premises in his speech only the conclusion and complement premise (enthymeme) and give example will make their argument stronger so audience can visualize it (Aristotle, 2008).

-Example of enthymeme: a. Major premise: All men are mortal

b. Minor premise: Aristotle is man

c. Conclusion: Aristotle is mortal

d. Enthymeme: Aristotle is mortal ......Aristotle is man

From three kinds of syllogism above, the most frequently used and known as the rhetoric syllogism is enthymeme that introduce by Aristotle.

The character or the authority of speaker in delivering speech is the thing that must be achieved by the speaker so that he or she can be trusted and judge credible by audience that ethos is (Aristotle, 2008). It really bring big effect for the speaker for instance a good man as the speaker will be heard more by the audience than a bad man.

Concerning audience emotion and trying to put them into a certain frame of mind is called pathos (Aristotle, 2008).

Those effective means of persuasion use "topic" to build premises into argument through logical strategies such us a cause effect way for arguing. The purpose of this principle is to brainstorm on what will be said (Mulder, 2019).

\subsection{Arrangement (dispotio)}

Arrangement refers to the distribution of these arguments in a proper order (Murphy, 2006). Kennedy also stated that arrangement is the way a speaker organizes the speech into some parts, though the order in which argument presented for instance a speaker organizes it from strongest or toward a climax (G. A. Kennedy, 1994). Every effective rhetor or orator understands that in most conventional situation a text must have a beginning, middle, and an end. Moreover a rhetor or an orator also should 
consider the principles of the ancient rhetoric that are first catching the attention of audiences (introduction), second providing necessary background information thus stating and proving the central idea (middle), then anticipating and addressing possible ideas, and finally concluding by appealing to the emotion of the audiences (end or conclusion) (Covino \& Jollife, 1995). This process` are to place the words, premises and arguments in certain place to gain the audience attention and to convince them through the structure of our arguments.

\subsection{Style (elocutio)}

Once the speaker has planned "what" to say and the arrangement in which to convey it, the next principle is to concern how to convey it, that is how to embody it in words and sentences, called "style" (elocutio) (Kennedy, 1994). This principle involves discussions of language levels, the grand, the middle, and the low such us the explanations tropes (figures of thought) and schemes (figures of actual expression) (Covino \& Jollife, 1995). From both definitions above, the writer can draw conclusion that style is the moment when a speaker finds out and chooses the appropriate words (diction) with the use of figures of speech (tropes and scheme) to convey his or her ideas.

Tropes refers to how the speaker connotes certain meanings by using words particularly that made it closely linked to the premises and conclusion of an argument (Martin, 2014). The one that is used the most in rhetorical tropes is metaphor which concerns words or phrases that transfer its meaning which is different with its basic sense (Szczesny, 2017).

Example of metaphor:

"A woman that sits next to me is called the flower of the village"

The metaphor used in this example is "the flower" that transfers its meaning as the most beautiful girl in a village from its basic sense as a plant.

\subsubsection{Schemes (figures of factual expression)}

Heighten its effect through repetition, word order and omission of words in the way the speaker arrange his or her speech is called schemes (Martin, 2014). Example of schemes: "Ask not what your country can do for you, ask what you can do for your country"(J. F. Kennedy, 1961). From the example above we can see the use of repetition in inaugural speech of J. F. Kennedy (1961) to heighten his speech

\subsection{Memory (memoria)}

Reading a speech has a less powerful effect (Mulder, 2019). That is why a speaker expected and needed to remember the words, quotes in his speech which is the next principle called memory (memoria). The most commonly mnemonic method used by a rhetor is to associate the sections of the speech through visual images in some specific physical setting (Covino \& Jollife, 1995). 


\subsection{Delivery (Pronuntio/Actio)}

And the final principle of rhetoric based on Cicero's point of view is delivery (Pronuntio/Actio). This is about the management of voice and gestures in oral discourse (Richard, 2020). So the writer can conclude that in delivering speech, a speaker must pay on his or her facial expression and tone of voice.

The universal facial expressions consists of several types which are surprise, fear, disgust, contempt, anger, sadness and happiness (Ekman, 1972). And to analyze deeply on facial expression, we used MicroExpressions which consists of eyebrows, eyes and mouth (Cuncic, 2020).

\section{-Eyebrows}

They can be...

*Raised and arched (surprise).

*Lowered and knit together (anger)

*Inner corners drawn up (sadness)

-Eyes

*Wide open (surprise)

*Intensely staring (anger)

*Have crow's feet crinkles (happy)

-Mouth

${ }^{*}$ A dropped jaw (surprise)

*Open mouth (fear)

*One side of the mouth raised (hate)

*Corners raised (happiness)

*Corners drawn down (sadness).

Tone of voices are classified into four dimension includes humor, formality, respectfulness and enthusiasm (Moran, 2016). While analyzing the tone voice, intonation can be the item that might help to interpret it. Intonation can be classified into three types which are falling intonation (usually used to say wh-question and something definite), rising intonation (usually used to say yes-no question) and fall-rise intonation (usually used to say uncertainty and may have more to add) (Cambridge, 2021).

\section{The rhetorical effects}

Rhetorical effect refers to the interpretation of the change of the situation after the speech conveyed by the speaker (Martin, 2015). As 
explained in a previous part, a political speech is delivered in a certain occasion such us in responding an incident or an event, there must be a reason it delivered, and the condition after the speaker's response through speech that meant as rhetorical effects. To know the condition after the speech delivered, news could be the best way to answer it. News is information or reports about current events (Cambridge dictionary).

\section{METHOD}

The method used in this research was descriptive qualitative method, which was defined by Miller \& Benjami (2000) as the method based on meaning expressed through words, and collection results in nonstandardized data requiring classification into categories and analysis conducted through the use of conceptualization.

Therefore, the research used qualitative approach to explore PresidentTrump political speech on the killing of Qassem Soleimani and specificallyused James Martin's theory (2014) of rhetorical analysis of political speech and Cicero's classical canons in Aristotle (2008) concerning five principles of rhetoric analysis of rhetoric in answering three questions of the research.

The writers got the data from the video, the transcript and the news that linked back to the speech of Donald John Trump, the current President of United States of America at the time, delivered in Palm Beach, Florida on January 3, 2020 on the killing of Qassim Soleimani. The video of the speech was uploaded by the Whitehouse Youtube channel and the transcript of the speech was released by online website of Whitehouse Government magazine and also from all kind of news such us online news to know the effect of the political speech delivered by President Donald Trump in Palm Beach, Florida on January 3, 2020 on the killing of Qassem Soleimani.

Donald John Trump was the current President of United States when the killing of Iran top General Qassim Soleimani occurred. He was born in Queens, New York, on June 14, 1946. Meanwhile Qassim Soleimani was the Iran revolutionary guard commander, and he was the Iran top general till the end of his life. He was born in the Rabor district of Kerman Province in Southeastern Iran on March11,1957

In collecting data, the writers used note taking as the instrument of the research. Note taking was used to identify and classify data that are suitable with the theory of rhetorical analysis. Finally the writers analyzed the rhetoric in the speech of Donald John Trump in Palm Beach, Florida on January 3, 2020 specifically on its rhetorical context, rhetorical argument and rhetorical effect.

\section{FINDINGS AND DISCUSSIONS}

Rhetorical analysis should be concerned with three distinct-moments of a speech intervention, each of which combines structure and agency in a 
particular way and hence serves as a separate area for interpretation (Martin, 2015).

\section{Rhetorical context}

To know why the speech should be delivered at the time, we need to see on the rhetorical context of the speech. In the findings there were three data presented by the writer to answer the rhetorical context of the speech. Datum (D: 1), the quoted speech of President Trump, stated that "Last night, at my direction, the United States successfully executed...... .....Qassem Soleimani" was the main idea of the speech which meant that he admitted as he ordered the killed. It could be the rhetorical context based on concerning the text and the writer.

The second datum (D: 2), the news of United States killed Iran Top General Qassem Soleimani was the occasion, purpose, and exigency of why the speech must be delivered at the time was responding and clarifying why United States killed Iran Top General Qassem Soleimani. What was his concerned in killing him? Why did he kill general from another country?

On the other hand, the news of United States killed Iran Top General QassemSoleimani was spread quickly to the world within hour through online media and social media. It made the citizens around the world gave their reactions on it. It is showed in datum (D: 3),\#WWIII after the killing of Qassem Soleimani led the worldwide trends on twitter. And the \#WWIII told us that citizens around the world assumed that because of United States killed Iran General Qassem Soleimani, they had been accused in starting the World War III, so accusation should be also clarified by President Trump. This case showed the purpose, exigency, and audiences of the speech.

Concerning the text, purpose, exigency and audiences of the speech is the way to find out its rhetorical context that related to what Martin (2015) stated of rhetorical context.

\section{Rhetorical Argument}

In order to know how the speaker ideas in the speech, we need to analyze the rhetorical argument of the speaker speech. Cicero, one of the most influence orators of Ancient Roman, introduced five principles of rhetoric to analyze further on rhetorical argument which comprises invention/discovery, arrangement, style, memory and delivery.

\subsection{Invention/Discovery}

The first process in knowing the rhetorical argument of the speech is finding out its theme or called invention. There are two ways in analyzing the invention of a speech which is finding out the stasis of the speech and the three means of persuasion comprises logos, ethos, and pathos.

Stasis of the speech refers to questioning the fact or the issue that responded. The writer raised a question of this case: did United States or President Trump admitted the killing of Iran general Qassem Soleimani? The datum presented by the writer which was the quoted speech of President Trump showed that He admitted the killing of Iran general Qassem Soleimani 
was directed by him. In his speech He stated that "last night, at my direction, the United States military successfully executed ... Qassem Soleimani". So the question raised by the writer had been already answered by the speaker in his speech which can be the theme of his speech.

President Trump in his speech on the killing of Qassem Soleimani used thethree means of effective persuasion. In the data datum he was reasoning logically byusing enthymeme or the rhetoric syllogism which presented his reason why he killedIran general Qassem Soleimani. He stated that "Soleimani was plotting imminent andsinister attacks on American ...". Then in the next passage he added that "Under my leadership to terrorist who harm or intend to harm any American, they will find you; they will eliminate you ...". From his arguments, we can know that the reason why he ordered the killing of Soleimani because he assumed that Soleimani was plotting imminent attack on American even in the next passage he did not provide any evidence of the imminent attack plotted by Soleimani.

And the next datum told us the authority or the role of the speaker (ethos), that he was the president so he had the authority in clarifying the killing of Qassem Soleimani as he stated "As president....".

Then the three data of pathos showed us how President Trump touched the various character of human being. Datum represented the human character of threat fear and protection. A threat for people that intend to harm any American and the feeling of protected for any American as he stated “...who harm or intend to harm any American,... we will eliminate you...". And the datum represented the human character of being respect and proud that President Trump did for Iranian as he stated "I have deep respect for the Iranian people...". Then the last datum, datum represented the human character thattends to the goodness as hestated "America will always pursue the interest of good people, great souls...".All the pathos used by President Trump was his strategy in shaping his audiences mind to his mind.

Therefore reasoning logically (logos), having an authority or role among audiences (ethos) and knowing the various character of human being (pathos) that had already been applied by President Trump were related to what Aristotle (2008) stated as the way to reach an effective mean of persuasion in rhetoric. Furthermore, it is also related to the previous study of Widyawardani (2016) which is called as rhetorical proofs.

\subsection{Arrangement}

Putting arguments into a proper order is the next process after discovering ideas. To know the arrangement of President Trump speech, the writer used the general way which divided the speech into introduction, middle and end. Datum showed us that in President Trump introduction speech, he greeted and introduced his self as president which is the best way in getting the audience attention. And in the data, it is showed that the middle part of the text which contained the content of the speech using the strategy of giving argumentation that was the cause-effect strategy to attract his audience comprised into main idea and supporting ideas. And in the end of 
the speech which contained a praise to Iranian, address possible ideas to support his conclusion of his speech in datum 21 that is related to Covino \& Jollife (1995) on how to arrange arguments into proper order. Furthermore last but not least is his conclusion "America will always pursue the interest of good people..."and gratitude "Thank you...".

\subsection{Style}

The process of choosing the appropriate words for our audience to convey our ideas that might influence them is called style. This part also explained the used of figures of speech specifically metaphor and schemes. The speech of President Trump, he used metaphor and scheme to convey his ideas but mostly he used form all types of word or the basic sense of words, so the writer only found two data in this process.

In datum "The world is a safer place without these monsters", President Trump used the word "monster" to portray the terrorists which are sinister and abusive. The word monsters itself means an ugly, large and frightening animal. Here we can see the use of metaphor by President Trump where the word "monsters" transferred its meaning from its basic sense as an animal to human being.

In datum, we can see the use of repetition by President Trump toheighten his argument. He tried tothreatthe terrorist with his argumentthroughrepetition as he stated "We will find you, we will eliminate you...". The use of repetition also was found in the next datum which emphasized President Trump's arguments that he did not start a war by killing Iran general Qassem Soleimani. as he stated "We took action lastnight to stop a war, We did not take action to start a war".

\subsection{Memory}

This process focused on speaker memory in delivering a speech. After watching the video the writers could say that Presidet Trump has a good memory. It was because along President Trump delivered his speech he never looked at a paper or a text. It relates to what Mulder (2019) stated that the way the speaker delivered his speech without stuck on his paper/text along the speech delivered is more powerful than delivered a speech but stuck on the paper or text and ignoring his audience (Mulder, 2019)

\subsection{Delivery}

This final process of Cicero`s classical principle of rhetoric refers to how the speaker delivered his speech by concerning two points, the facial expression and tone of voice.

To analyze the facial expressions showed by President Trump, the writer used Ekman's (1972) theory of universal expressions and Cuncic's (2020) theory of micro-expressions. Thus data taken from video presented the portrait of Trump's facial expressions when delivering the beginning until at the end of his speech. In the beginning of his speech showed the 
facial expression of happy and fear. His happiness came from the death of Qassem Soleimani killed by United States military and his fear came for assumption of what would come to his nation after it. Then the datum presented President Trump`s facial expressions in middle of delivering speech portrayed the contempt facial expression while the micro expression used by him was one side of mouth raised which means hate.

And finally the datum showed President Trump facial expressions in the end of his speech which were happy, and the micro-expression used by him was opened mouth which means fear. President Trump of course showed his happiness after killing Iran Top General Qassem Soleimani, but he could not hide his fear of what would come next.

Through the video data analysis, the writer found that President Trump used two types of tone of voice that were respectfulness and formality to convey his speech. It was proven in data where in introduction he used respectfulness type of tone of voice to great his audience and praise his nation and its citizen especially to his defense. In the middle of the speech, he used formal type of tone of voice conveying the fact. Then in the end of his speech he used respectfulness and formal types of speech, both tones of voice were used to praise Iranian and pray to his nation; and formal was used to conclude his speech. Furthermore, he used two types of intonation along his speech which were falling intonation to convey his definite ideas and fall-rise intonation that means uncertainty, or he would add more arguments.

\section{Rhetorical effect}

The interpretation of the situation after the speech delivered responding on an event or a case is called rhetorical effect. The speech of President Trump was delivered to respond and clarify the killing of Qassem Soleimani. In his speech he conveyed that the assassination of Soleimani was done under his direction. Then he provided the reason why he ordered the assassination in the next passage.He stated also that he took the action to stop the war not to start the war. But unfortunately, even he said bend the war it was absolutely raised tensions in the region especially between United States and Iran. It was showed in the news released the reaction of some leaders across the world (datum 37)that interpreted what United States did yesterday (killed Soleimani) had raised tension in the region.

Then five days after the speech delivered the tension appeared between United States and Iran. It was proven from the data taken from the news which informed Iran missile strike 50 troops of United States in Iraq and diagnosed suffered brain injuries. And immediately President Trump directed the troops to leave Iraq immediately.

Figure 1 (news of Iran attack on US troops) 


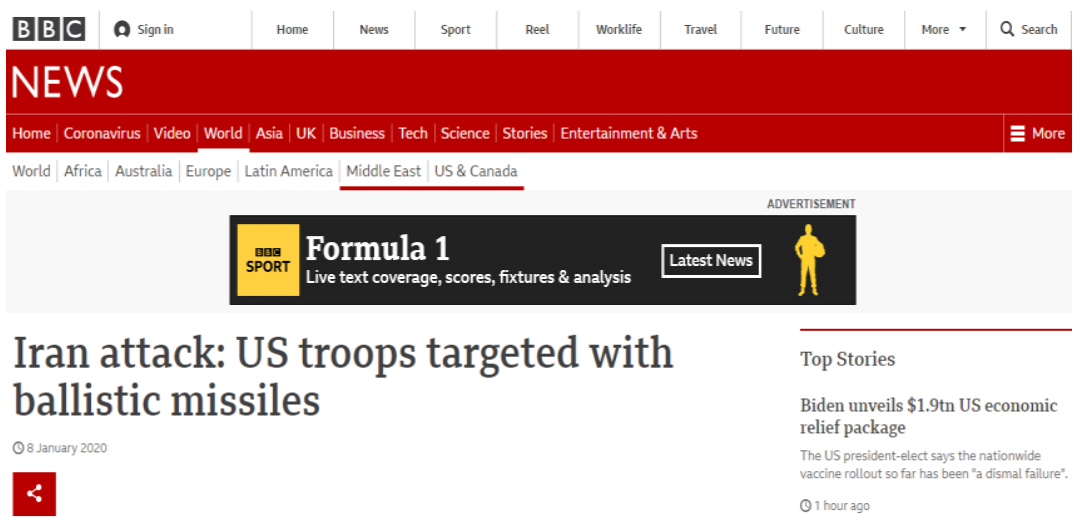

(Source: BBC News)

Figure 2 (the news of Iran missile strike on US troops)

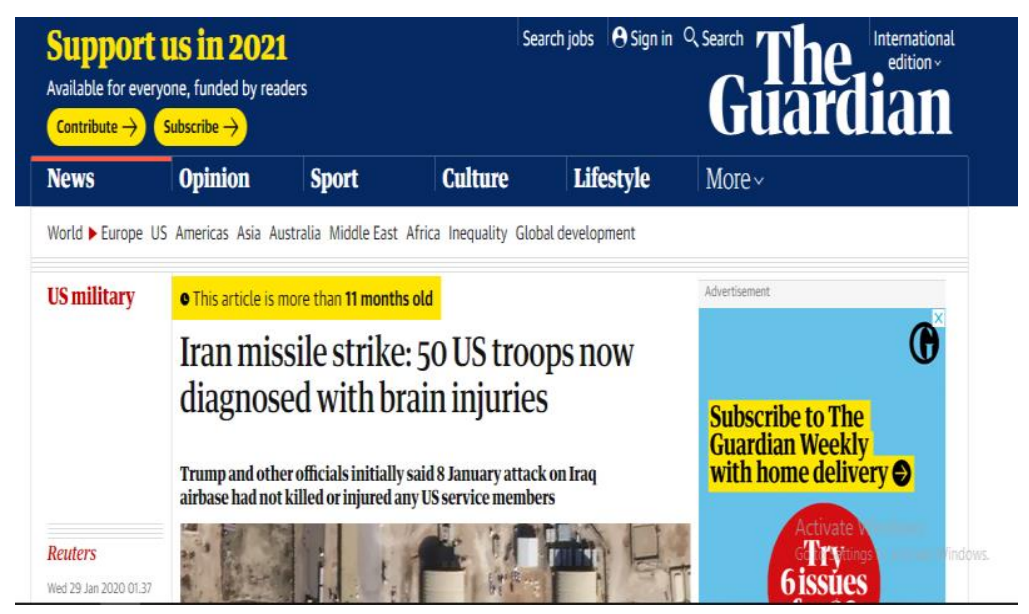

(Source: The Guardian News)

\section{CONCLUSION}

The conclusions of the research are the rhetorical context of President Trump political speech in Palm Beach, Florida on January $3^{\text {rd }}$, 2020 is to respond and clarify the killing of Qassem Soleimani in Iraq by United States military personnel and to clarify the accusation of citizens across the world that accused him starting the war by killing Iran Top General Qassem Soleimani. Thus, the rhetorical argument of President Trump political speech delivered in Palm Beach, Florida on January $3^{\text {rd }}$, 2020 on the killing of Qasem Soleimani was analyzed by the writer using the famous ancient Roman orator theory of classical principle of rhetoric. Cicero introduced five principles of rhetoric comprises invention/discovery, arrangement, style, memory and delivery. The writer found that in President Trump speech he used all the process of classical theory of rhetoric of Cicero in shaping his ideas into argument for his audiences. It was proven from the findings of the writer. In the first process he used enthymeme which is the way in rhetoric syllogism to reasoning 
logically and admitted the fact as the stasis of his speech in the beginning of his speech. The next process he used cause-effect strategy of arrangement to put his argument in a proper order. Then in style he used metaphor and schemes even some in conveying his meaning. He also did not stick on his text or paper along the speech showing his memory to have more powerful speech. And he also used the right facial expression and gesture in delivering his speech so did his tone of voice. He used two types of tone of voice in conveying his speech which were respectfulness tone of voice to great and praise his audience; and formal tone of voice to deliver fact and conclusion. Furthermore, he used two types of intonation which were falling intonation and fall-rise intonation to convey his ideas.

Meanwhile the rhetorical effect of President Trump political speech in Palm Beach, Florida on January3 ${ }^{\text {rd }}, 2020$ on the killing of Qassem Soleimani was escalating the tension in the region as he admitted the killing under his direction. It was proven from the reactions of leaders across the world and five days after the speech delivered the Iran missile strike 50 troops of United States in Iraq and diagnosed suffered brain injuries.

\section{REFERENCES}

Aristotle. (2008). The Art of Rhetoric. In W. R. Roberts (Ed.), Megaphoneebook. www.wendelberger.com

Covino, W., \& Jollife, D. A. (1995). Rhetoric: Concepts, Definitions, Boundaries. Allyn and Bacon.

Cuncic, A. (2020). How to Read Facial Expressions. VeryWellMind. https://www.verywellmind.com/understanding-emotions-through-facialexpressions-3024851

Ekman, P. (1972). Universals and Cultural Differences in Facial Expressions of Emotions. In J. Cole (Ed.), Nebraska Symposium on Motivation (pp. 207-282). University of Nebraska Press.

Ilie, C. (2006). Rhetoric, Classical. In Encyclopedia of Language \& Linguistics (2nd ed., pp. 573-579). Elsevier Ltd. https://doi.org/10.1016/B008-044854-2/04305-4

Kennedy, G. A. (1994). A New History Of Classical Rhetoric. Princeton University Press.

Kennedy, J. F. (1961). JFK's Famous Inaugural Address Passage. https://youtu.be/PEC1C4p0k3E

Martin, J. (2014). Politics and Rhetoric A Critical Introduction (1st ed.). Routledge.

Martin, J. (2015). Situating Speech: A Rhetorical Approach to Political Strategy. 63(1), 25-42. https://doi.org/https://doi.org/10.1111/14679248.12039

Miller, W. L., \& Benjami, F. C. (2000). Doing Qualitative Research. Sage Publication.

Moran, K. (2016). The Four Dimensions of Tone of Voice. Nielsern Norman Group. https://www.nngroup.com/articles/tone-of-voicedimensions/ 
Murphy, J. J. (2006). Rhetoric: History. In Encyclopedia of Language \& Linguistics (2nd ed.). Elsevier Ltd.

Sutherland, S. (2016). A Beginner's Guide to Discourse Analysis. Red Globe Press.

Syarif, S. (2015). Rhetoric Analysis of Michelle Obama's Speech at the Democratic National Convention On September 4th 2012. Alauddin State Islamic University.

Szczesny, S. (2017). Stylistic features of Barack Obama `s state of the union addresses. Leiden University.

Widyawardani, Y. I. (2016). RHETORICAL ANALYSIS OF DONALD TRUMP'S PRESIDENTIALCANDIDACYANNOUNCEMENT SPEECH [Universitas Sanaata Dharma Yogyakarta].

https://repository.usd.ac.id/4879/2/111214096_full.pdf 


\section{APPENDIX I}

Full text of President Trump political speech on the killing of Qassem Soleimani delivered in Palm Beach, Florida on January 3rd 2020.

\section{Mar-a-Lago Palm Beach, Florida 3:13 P.M. EST}

THE PRESIDENT: Hello, everybody. Well, thank you very much. And good afternoon. As President, my highest and most solemn duty is the defense of our nation and its citizens. Last night, at my direction, the United States military successfully executed a flawless precision strike that killed the number-one terrorist anywhere in the world, Qasem Soleimani. Soleimani was plotting imminent and sinister attacks on American diplomats and military personnel, but we caught him in the act and terminated him. Under my leadership, America's policy is unambiguous: To terrorists who harm or intend to harm any American, we will find you; we will eliminate you. We will always protect our diplomats, service members, all Americans, and our allies. For years, the Islamic Revolutionary Guard Corps and its ruthless Quds Force - under Soleimani's leadership - has targeted, injured, and murdered hundreds of American civilians and servicemen. The recent attacks on U.S. targets in Iraq, including rocket strikes that killed an American and injured four American servicemen very badly, as well as a violent assault on our embassy in Baghdad, were carried out at the direction of Soleimani. Soleimani made the death of innocent people his sick passion, contributing to terrorist plots as far away as New Delhi and London. Today we remember and honor the victims of Soleimani's many atrocities, and we take comfort in knowing that his reign of terror is over. Soleimani has been perpetrating acts of terror to destabilize the Middle East for the last 20 years. What the United States did yesterday should have been done long ago. A lot of lives would have been saved. Just recently, Soleimani led the brutal repression of protestors in Iran, where more than a thousand innocent civilians were tortured and killed by their own government. We took action last night to stop a war. We did not take action to start a war. I have deep respect for the Iranian people. They are a remarkable people, with an incredible heritage and unlimited potential. We do not seek regime change. However, the Iranian regime's aggression in the region, including the use of proxy fighters to destabilize its neighbors, must end, and it must end now. The future belongs to the people of Iran - those who seek peaceful coexistence and cooperation - not the terrorist warlords who plunder their nation to finance bloodshed abroad. The United States has the best military by far, anywhere in the world. We have best intelligence in the world. If Americans anywhere are threatened, we have all of those targets already fully identified, and I am ready and prepared to take whatever action is 
necessary. And that, in particular, refers to Iran. Under my leadership, we have destroyed the ISIS territorial caliphate, and recently, American Special Operations Forces killed the terrorist leader known as al-Baghdadi. The world is a safer place without these monsters. America will always pursue the interests of good people, great people, great souls, while seeking peace, harmony, and friendship with all of the nations of the world. Thank you. God bless you. God bless our great military. And God bless the United States of America. Thank you very much. Thank you. END 3:18 P.M. EST

\section{APPPENDIX II}

Link of the speech video

https://youtu.be/TYY29y08HIc 